\title{
Фенотипические характеристики растений табака, мутантных по генам семейства
} хинолинат фосфорибозилтрансфераз

\author{
Лыхина А. ${ }^{1,2 *}$, Костина Н. ${ }^{1}$, Домрачев Д. ${ }^{3}$, Спасельникова А. ${ }^{1}$, Томилин M. ${ }^{1,2}$, \\ Романова А. ${ }^{1}$, Герасимова С. ${ }^{1,2}$ \\ ${ }^{1}$ Институт иитологии и генетики СО РАН, Новосибирск, Россия \\ ${ }^{2}$ Новосибирский государственный университет, Новосибирск, Россия \\ ${ }^{3}$ Институт органической химии СО РАН, Новосибирск, Россия \\ *a.lykhina@mail.ru
}

Ключевые слова: гены биосинтеза никотина, табак обыкновенный, направленный мутагенез

Мотиващия и цель: Накопление никотина в листьях табака обыкновенного часто является неблагоприятным фактором при его использовании в биотехнологических целях. Нокаут ключевых генов биосинтеза никотина может привести к снижению его уровня. В настоящем исследовании технология Cas9/gRNA была использована для направленного мутагенеза гена хинолинат фосфорибозилтрансферазы 2 (QPT2), который участвует в синтезе пиридинового кольца молекулы никотина.

Методы и алгоритмы: На основе вектора RGEN (RNA-guided endonuclease), несущего кассету Cas9/gRNA, были созданы генетические конструкции, направляющие нуклеазу Cas9 к сайтам-мишеням, консервативным во всех двух гомологах гена QPT2 (LOC107820078 и LOC107829122). Эти конструкции использовались совместно для биобаллистической трансформации табака. Дополнительно к RGEN векторам в клетки табака вводилась плазмида на основе pBI121, содержащая ген устойчивости к канамицину и репортерный ген GUS. Селекцию трансформированных растений проводили с применением канамицина. Pезультаты: Были получены три клоновые линии Т0, в которых оба гомолога гена QPT2 оказались мутированными. Растения табака, подвергшиеся сайтнаправленному мутагенезу по гену QPT2, проявляли серьезные фенотипические аномалии, такие как ингибирование роста, уменьшение количества и размера листьев, лонгостилия и снижение фертильности пыльцы. Содержание никотина в листьях этих мутантов было в 6.5 раза ниже, чем в листьях растений дикого типа. Заключение: Предварительно можно заключить, что ген QPT2 необходим не только для биосинтеза никотина, но и для нормального роста и развития растений табака обыкновенного. Полученные растения представляют высокий фундаментальный интерес как модель для исследования функций отдельных генов семейства QPT.

Благодарности: Работа выполнена при поддержке проекта базового бюджетного финансирования Минобрнауки РФ (№ 0259-2021-0012). 